\title{
DISPLACED ROHINGYA SETTLEMENT AND SECURITY CONCERN IN BANGLADESH
}

\author{
MD MAHBUBUL HAQUE ${ }^{1 *}$, BUSSABONG CHAIJAROENWATANA ${ }^{2}$ \\ ${ }^{1}$ Faculty of Law and International Relations, Universiti Sultan Zainal Abidin, 21300, Kuala Terengganu, Malaysia. \\ mahbubhmu@gmail.com* (Md Mahbubul Haque) \\ ${ }^{2}$ Faculty of Management Sciences, Prince of Songkla University, Hat Yai 90112, Thailand. \\ bussabong.c@gmail.com (Bussabong Chaijaroenwatana)
}

\begin{abstract}
In Myanmar's post-independence history, the Rohingya and other ethnic minorities have been in conflict with the Rangoon based central government. It is commonly alleged that the Rohingya are involved with separatist movements that threaten Myanmar's sovereignty. The ethnic minority Rohingya were faced with sub-violent confrontation after the military took over State power and later, and most critically, they became de jure stateless in Myanmar. The situation changed dramatically after the 2012 BuddhistMuslim communal riots. Lastly, the quasi-civilian government launched 'operation clearance' against Rohingya civilians using the pretext of terrorist attacks on August, 2017. Since that operation, nearly a million terrorized Rohingya people crossed the border and sought shelter in Bangladesh. Almost three years on, after escaping the violence of the military in Myanmar, the refugees still live in uncertainty. This paper examines the conditions of displaced Rohingya living in different camps in Bangladesh and the extent that the Rohingya pose a security risk for host country. The Government of Bangladesh and international humanitarian agencies have been successfully handling the refugee exodus. But despite progress, it is clear that the Rohingya remain in a precarious situation. After intensive field work, it is concluded that a small minority refugees are involved with anti-social activities in Bangladesh whereas the large majority of Rohingya is innocent. Nevertheless, the refugees' long presence in border areas of Bangladesh is creating socio-economic pressure and environmental hazards on Bangladesh's limited resources.
\end{abstract}

Keywords: Bangladesh, Rohingya, Settlement, Security

Article Received: 18 October 2020, Revised: 3 November 2020, Accepted: 24 December 2020

\section{Introduction}

The Rohingya Muslim crisis is one of the longstanding conflicts in Myanmar political history. It is commonly alleged that the Rohingya are involved with separatist movements that threaten for Myanmar's sovereignty. From the end of 1950's ethnic minorities such as the Kachin, Karen, Shan even Rakhine armed groups often clashed with the Myanmar army. But the Rohingya problem is more complicated to compare other ethnic conflict in Myanmar. Rohingya oppression started after General Ne Win took over State power. "Irrespective of international pressures, the main institutions of the Myanmar government, military, major political parties, media and the radical Buddhist monks do not accept the Rohingya as citizens" (Haque,2020). They believed that this Muslim population changed the demographics of the western border region. So why government conducted various actions against the Rohingyas existence in Myanmar. It was started from mid 1960s then Rohingya statelessness was institutionalized by the Burmese 1982 Citizenship Law. As a result, they became unwanted people in their ancestors' in Arakan which is officially called the Rakhine State. The Economist (2015) stated that Rohingya formed the largest single group of "stateless" people in the world. Due to state sponsored violence and persecutions, thousands of Rohingya fled country since late 1970s. Bangladesh faced two times Rohingya refugee inflows in twentieth century. "The first occurred in 1978, and second in 1991-92. Each involved more than 250,000 refugees" (Haque,2014. p.231). Despite repatriation, the Rohingya situation has not improved inside of Myanmar and getting worse after the 2012 Buddhist-Muslim communal riots. Later, under the NLD regime, Myanmar military conducted two-phases 'operation clearance' against the Rohingya civilians on October 2016 and 
August 2017. Marzuki Darusman, chair of the U.N. fact-finding mission on Myanmar stated that, "genocide is still taking place against Rohingya Muslims remaining in Myanmar and the government is increasingly demonstrating it has no interest in establishing a fully functioning democracy" (Lederer,2018). According to International Rescue Committee (2017) the Rohingya refugee crisis is now the world's fastestgrowing humanitarian crisis by the numbers. Aftermath of operation, nearly a million of terrorized Rohingya people crossed the border and sought shelter in Bangladesh.

According to international agencies Join Response Plan for Rohingya Humanitarian Crisis (2019), "it can be estimated that over 3,000 hectares of land in southeast Bangladesh (Cox's Bazar) have been converted to temporary shelter and emergency humanitarian modalities for over 900,000 refugees." In addition, Rohingya refugees' presence have socio-economic impact on local peoples' livelihood and overall environmental damage cannot recover within next two decades. In particular, this paper tries to find the situation of displaced Rohingya ethnic minority in Bangladesh and their presence poses any security risk for host country.

\section{Methodology}

This study was conducted to understand the situation of displaced Rohingya in Bangladesh and how displaced community become security concern for host country. This paper is based on firsthand information and it gathered from two round field works at Rohingya refugee camps and various documentary analysis. Regarding the objectives and questions of this research, case study method is helpful to analyze the displaced Rohingya situation and how they are treated in Bangladesh. Through this method, it is relatively easy to understand how the displaced Rohingya face difficulties and make vulnerabilities for the host community.

This research has conducted field work in the Rohingya refugee camps at Bangladesh-Myanmar borderland. The nature of this research demonstrates an intensive review of the displaced Rohingya, ideas of security and relevant documents of the Rohingyas' presence in Bangladesh. The researcher collected data from the refugee areas during the first week of November 2018 and August 2019. This research is also based on observations of the socio-economic and security conditions of Rohingya residential areas in Bangladesh which provided unique insights into the whole scenario of this community. Through use the observation as a research technique, the researcher ascertained the neighbors' views of Rohingya in Bangladesh as displaced. During the field work, researcher had taken interview with the refugees', Rohingya political leaders, government and INGOs officials, members of local civil society, and then checked with relevant experts on the subject. It should be mentioned that aftermath of last influx, Bangladesh government deployed military to conduct humanitarian activities. Due to lengthy bureaucratic procedure, researcher could not talk directly with military officials in Bangladesh.

\section{Findings And Discussions}

\subsection{Rohingya Atrocity in Myanmar}

The main aim of this paper is to analyze the situation and treatment of displaced people from Rakhine State and their presence created any risk for security or not in Bangladesh. Before going to discuss Rohingya situation in Bangladesh, this paper briefly explores the Rohingyas identity, existence and their struggle in Myanmar. Historically the Rohingya ancestors land-Arakan, western frontier of today's Rakhine State in Myanmar was not part of the Burmese kingdom. From ancient time, it was closer with the Bengal. Independent kingdom Arakan conquered by Burmese king Bodayapaya in late 1784. Within the time, the Arakanese Buddhists were melted and mixed with the Burmese until they became one same piece. During the British colonial period, many South Asian origins migrated in present Myanmar and mostly settled in urban areas. The Rohingya or Muslims of Arakan separate identity in Myanmar was quite different from Muslims of 
South Asian origin. Until 1962, the Rohingya Muslim people of the western frontier did not face any identity problem in Burma/Myanmar. This was highlighted when the 1982 Citizenship Law enacted on the basis of so-called indigenous ethnic. Even the new law was not enforced until late 1980s.

The situation changed dramatically after the 2012 Buddhist-Muslim riots and massacre of Rohingyas in Rakhine state. Moreover, the post-2015 Daw Aung San Suu Kyi-led quasi-civilian government failed to improve the situation especially in Rakhine State (Chaijaroenwatanaa and Haque, 2019). The international community was highly critical about the role of the Union Government in not protecting the Rohingya and other Muslim minorities in Myanmar. The National League for Democracy (hereafter NLD) secured a landslide victory and formed the democratically-elected government in Myanmar on April 2016 after nearly half a century. To find a lasting solution to the issues in the Rakhine State, NLD government had formed a nine-member Advisory Commission chaired by former U.N. Secretary General Kofi Annan. The overall objective of the Commission is to provide recommendations on the complex challenges facing the Rakhine State (Haque, 2017). It should be mentioned that members of the former ruling party and a splinter group from Aung San Suu Kyi' s party also released a statement against this commission.

In the name of terrorist attack, Myanmar's army chief has urged the country to unite over the "issue" and simultaneously military trying to justify "operation clearance" in northern Rakhine state (Agence France-Presse, 2017). In 2017, the world was appalled by the images of hundreds and thousands of innocent Rohingya men, women and children fleeing mass atrocities. The 2018 report of the UN Human Rights Council (HRC) mandated Fact-Finding Mission (FFM) on Myanmar concluded that the military, as well as some civilians, have committed genocide and war crimes against its own people (OHCHR, 2018). Aftermath of military action, "more than 740,000 Rohingya Muslims have fled to Bangladesh since August
2017 to escape the Myanmar military's campaign of ethnic cleansing and crimes against humanity. They joined about 200,000 refugees who had fled previous waves of violence and persecution" (Human Rights Watch, 2019). It was the second military attack on Rohingya civilians in northern part of Rakhine State by Myanmar security forces under the NLD regime.

\section{Rohingya Displacement in Bangladesh} Myanmar political history suggested that Rohingya ethnic minority people fled into Bangladesh and it was started after Burmese king Bodawpaya invaded the Arakan. Due to geographical location, Bangladesh has been carrying large number of Rohingya refugee in different periods; 1978, 199192, 2016-17. "Though after the 2012 communal riots, many Rohingya tried to enter Bangladesh, but border guards forced them back to where their lives were at risk" (Haque, 2014. p.136). The Bangladesh Government open the border after second week of October 2016 and initially local people welcomed the displaced Rohingya from Myanmar. It can assume that Sheikh Hasina led government more sympathize on Rohingya and during her visit in camps on September 2017, she stated that "Myanmar needed to take steps to take their nationals back" (Safi, 2017). At the same time, Bangladesh does not want to recognize them refugee prefer to addressed them Rohingya as "Forcibly Displaced Myanmar Nationals" (interview with Deputy Refugee Relief and Repatriation Commissioner at Cox's Bazar in Bangladesh, November 7, 2018). There is no doubt that the Rohingya are "refugees" according to the UN Convention Relating to the Status of Refugees, "someone who is unable or unwilling to return to their country of origin owing to a well-founded fear of being persecuted for reasons of race, religion, nationality, membership of a particular social group, or political opinion" (UNHCR, 2010). The UN system and other international agencies called this population as 'Rohingya refugees' (interview with IOM official based in Cox's Bazar, Bangladesh, November 8, 2018). It should be mentioned that refugee protection and assistance in 
Bangladesh is highly influenced by the country's lack of legal framework. Bangladesh is not signatory of the Refugee Convention of 1951 and its Additional Protocol in 1967. Additionally, there is no national or regional refugee law to address this non-citizens issue. "From a legal perspective, Bangladesh has no particular law to deal with refugee and asylum seekers" (Haque, 2014.p.253). In this research, authors refer to Rohingya both 'displaced' and 'refugee'. In Bangladesh, the Ministry of Disaster Management with its local office of the Refugee Relief and Repatriation Commissioner (RRRC) in Cox's Bazar is in charge of the administration of camps and repatriation strategies.

This research has conducted two round field works at Rohingya refugee camps in the southeastern border district Cox's Bazar. According to the International Organization for Migration "since August 2017, an estimated 730,000 Rohingya (more than 400,000 of them children) arrived in Cox's Bazar, Bangladesh, after fleeing from the violence in Rakhine State, Myanmar. As of November 2018, over 900,000 stateless refugees reside in Ukhiya and Teknaf Upazilas, with the majority living in 34 extremely congested camps" (IOM, 2019). This research field work witnessed that displaced Rohingya shelters are situated in disaster prone areas. Rohingya community people are dependent on humanitarian support from national and international agencies. Their freedom of movement is strictly controlled by the law enforcers in Bangladesh.

The International Organization for Migration (IOM) is taking preparation to support a total 1.2 million Rohingyas considering previously migrated Rohingya populations and expected number of newly birthed children (IOM Bangladesh: 2019. p.2). Among the people who have crossed the border since 25 August 2017, the majority of them are women and girls (65\%), this means 447,200 women and girls. Among those women, $20 \%$ of them are either pregnant or breastfeeding. So approximately 26,000 newly arrived pregnant and lactating women have migrated (IOM Bangladesh, 2019.p.3). It is noted that the Rohingya people, arriving in Bangladesh, mostly women and children are traumatized.

The global Christian humanitarian organization, World Visions stated their field report, "aid agencies are struggling to adequately serve 1.2 million people who need assistance, including those in local communities" (Huber \& Homer, 2020). Bangladeshi primary school teacher mentioned that Rohingyas are getting preference during the aid distribution (interview with locals at nearby refugee camps on August 3, 2019). This study field work observed that local people also getting treatment in Malaysian Field Hospital. The Malaysian Armed Forces (MAF) build a field hospital at the Rohingya refugees camps since November 2017. There is strong perception among the locals that Rohingyas are only eligible for humanitarian supports. It makes tension between the locals and displaced people from Myanmar. "Over 16 million litres of safe water are needed per day for the Rohingya refugee population; 12,200 metric tons of food are required per month to sustain the refugee population" (World Food Program, 2018). Refugee people are not much happy on the food supply, according to their statement, "we have no choice but have to feed same food in every day, our people are not allowed to work in here, as a result we have no local currency to purchase fish or chicken from market, only Qurbani time we can eat meat" (interview with anonymous refugees at camps, August 2, 2019).

It can be stated that most of the refugees are children and women. Many families' male members either killed or still detained inside Myanmar (Othman, Haque and Mat, 2019). The UNICEF currently "provides informal education opportunities to 220,000 Rohingya children aged 4 to 14 years based on a tailor-made curriculum called the Learning Competency Framework and Approach" (UNICEF, 2020). In addition, UNICEF officials expecting that they can introduce Myanmar curriculum on a pilot basis for Rohingya refugee children in Bangladesh. 
However, the displaced Rohingya become a new point of concern on many dimensions. Besides enormous catastrophe due to large exodus of Rohingya community in Bangladesh, there is an apprehension of security threat which ultimately might expand to the surrounding countries, if the matter is not well-addressed by policy makers. Apart from traditional security, "the western part of Myanmar is also known to be a golden passage for drug traffickers" (Dhaka Tribune, August 24, 2017). In many of the cases, the Rohingya population was actively involved in this kind of trafficking and transportations of drugs. The present situation of the Rohingya community might influence them more to take part in these kinds of crimes, which might create a new avenue for transnational mafias.

\section{Conflict among the Refugees}

There are few thousands of Hindus living in Maungdaw, Buthidaung and Sittwe under the Rakhine State. It should be mentioned that Hindu people of Rakhine States have ethnic kinship with Rohingya Muslims. During the Operation Clearance, many Hindus were internally displaced while others crossed the border and sheltered in neighboring Bangladesh. "The 400 Hindu refugees in Bangladesh are segregated and housed in a separate facility called Hindu Camp, which is under round-the-clock security" (cited in India Today, 2019). This study also conducted interview with the ethnic Rohingya Hindu refugees in makeshift camps. Beginning of the conversation, they feel nervous to share experience with Bangladeshi people especially with Muslims. Later, some of researchers' Hindu colleague, who has been working in INGO facilitated to meeting with them. Hindu Rohingya refugees are living away from the Rohingya Muslims refugee camps. After entering in Bangladesh, they do not want to live with the Rohingya Muslims. As a key informant of this study (Gourango, not his real name) stated that, "his relatives killed by the Arakan Rohingya Salvation Army (hereafter ARSA) and their members sheltered in Bangladesh after Myanmar military crackdown. Hindu
Rohingya refugees in Bangladesh willingly to go back home and do not feel complications with Myanmar government" (interview at Cox's Bazar, November 6, 2018). Amnesty International report also mentions that, "photographic evidence analyzed by forensic pathologists, the organization revealed how ARSA fighters sowed fear among the Hindus" (Amnesty International, 2018). Through the informal conversation with Rohingya Muslims community, it can be stated that they have no bad impression on Hindus but some of them close to Rakhine Buddhist and security forces.

The Human Rights Watch (2020) and Fortify Rights (2020) concern about the scared situation on ethnic Rohingya Christian communities at camps. "Taher, a Rohingya Christian pastor, and his 14year-old daughter were abducted from their shelter in a refugee camp in Bangladesh on the morning of January 27" (Adams, 2020). It is worth mentioning here that traditional Rohingya community comprised of Muslims and Hindus, but recently few people convert into Christian. A few number of Rohingya Christians are also living in same refugee camps at Cox's Bazaar. Brad Adams, director of the Human Rights Watch stated that, "the attackers beat up residents, vandalized homes, and looted personal property in the sprawling Rohingya refugee camp" (ibid). The Rohingya Refugee Committee strongly deny the false accusations of terrorist attack on the Christian community in the refugee camps (RRC, 2020). After attacked, Christian community filed a case against the Rohingya Muslim refugees. Based on their allegations, nearly a hundred innocent Rohingyas have been taken into police custody (email conversation with Ko Ko Lin alias Mohammad Kalim, March 29, 2020). Matthew Smith, Chief Executive Officer of Fortify Rights stated that "no Rohingya should experience violence and abuse in the camps, regardless of their religion" (Fortify Rights, 2020). The role of Rohingya militant group ARSA will detail discuss later of this article. 


\section{Conflict with Locals and Human} Security Threat for Bangladesh

The huge number of displaced Myanmar nationals in Bangladesh is having severe impact on socioeconomic, demographic, environmental and security situation of Cox's Bazar and adjacent hill districts. Local people are sympathized during the early days of influx. However, the overall situation has been changed. It should be mentioned that after nearly three years of refugee influx, local people perceived that refugees are a relatively privileged group. They believe that most of the donors including UN agencies have always been highly concerned only for Rohingyas basic and social services including nutrition, health care, education and adequate housing (interview with local Bangladeshi community nearby refugee camps, November 5, 2018). This research witnessed that there are lots of misconception among the Bangladeshi people on refugee situation in borderlands. The refugees' long presence has also impacted on the labor market causing local unemployment. Though, Rohingya refugees are not allowed to move outside of the camp.

\section{Environmental Damage}

The Rohingya refugee areas environmental damage is very high and it cannot compensate in the next twenty years. UNHCR's Environmental Guidelines stated that "refugees may impact host communities' environment by the six categories: natural resource degradation; irreversible impacts on natural resources; impacts on health; impacts on social conditions; social impacts on local populations and economic impacts" (cited in Martin, 2005, p.332). This study observation witnessed that their housing is in bad shape, and inadequate cooking and sanitation facilities are common problems in camps. The overall environment inside and adjacent camps getting wore since the October 2016. "After the three years of influx, aid agencies failed to develop hygienic sanitation systems for refugees" (interview with local NGO worker Ayub Gazi, August 01, 2019).
The refugee crisis and its impact on environment and natural resource of the host community has become important issue for policy makers and aid agencies. To address the environmental impact on refugee areas, a join study conducted by the United Nations Development Programme (UNDP) and UN Women. This study report highlighted that, "a total of 4,300 acres of hills and forests were cut down to make temporary shelters, facilities and cooking fuel in Ukhia and Teknaf of Cox's Bazar, threating the biodiversity of the three ecologically critical areas of the country" (UNDP, 2018). In addition, "United Nations Development Programme identified 28 risk factors for threatening biodiversity and human security" (cited in Alam, 2018). Damage of natural resources and ongoing biodiversity threat has link with Bangladesh economy. "The value of forest land occupied by the Rohingyas has been estimated to be BDT 500 crore [59,269,450 USD]" (Khatun, 2017). The international humanitarian agencies and Bangladesh Government cannot ignore the environmental impact on whole southwestern part of Bangladesh. This study field work witnessed that there is no more natural forest after refugee influx in border areas. Local people argues that, "this forest famous for wild elephant but now you can find a single tree over there" (interview with local government representative, August 1, 2019) It can be stated that refugees are not intentionally polluting the environment, rather it was lack of awareness. "Wood is the main source of fuel for the Rohingya refugees for cooking which is being collected mainly from the protected forest reserves" (interview with refugee leader Muhammad Faruq, November 7, 2018). In addition, refugee settlement and adjacent areas air polluted by the aid agencies thousands of vehicles movement in every day. To some extent, it was necessary to supply food stuffs from the big city to refugee areas.

Bangladesh is a densely populated and riverine country of the South Asia. Here people survived with tropical storms, soil erosion, rising sea levels, flooding and other natural disasters. The United Nations Development Programme conducted study 
pointed that, "water levels around the Rohingya camps have fallen by around 5 to 9 metres because of excessive dependence on groundwater in the areas where forcibly displaced people have taken shelter in Cox's Bazar" (UNDP,2019). So why the local residents annoyed this situation and seeking assistance from the government to stop overall environmental damage (interview with local government representative Abdul Halim, adjacent refugee camps, November 8, 2018).

The displaced Rohingyas long presence have changed the demographic scenario especially in borderland. The total refugee population is double compare to local community in Rohingya residing areas. All these places are overcrowded and living conditions lack minimum hygiene. "The birthrate among the Rohingya is also much higher than that of Bangladeshis; in 2018 alone, experts expect refugees to give birth to 48,000 babies - who will face severe risks of malnutrition, disease and death" (The Washington Post, February 12, 2018). Polygamy is a common trend in Rohingya society. Some Rohingya men engage in malpractice in the name of religion and local custom. This research filed work witnessed that in refugee life, Rohingya people used to practice polygamy frequently. Community leaders have denied this. Ko Ko linn, an ethnic Rohingya and 88 Generation student leader, argued that "it can be happened accidentally, but it is not normal trend of this society" (interview, Chittagong, November 9, 2018). In addition, local representatives and law enforcers instructed by the government to barred for marriage with Rohingyas.

\section{Rohingya and Trafficking}

The prolonged refugee-life and uncertainty of the Rohingya is a push factor for them to find livelihood opportunities in Southeast Asian countries. As a result, the Rohingya, especially young people, are desperate to go outside of the refugee camps. Basically, the traffickers operating inside of the camps start to give promises to the Rohingya that they can be provided with an escape route, with ships that will bring them to Malaysia. It is reported since 2009, larger number of
Rohingyas unregulated sea journey in the Bay of Bengal towards mainly Malaysia and many of them died due to dehydration and other causes. Chris Lewa, director of the Arakan Project, Bangkok based monitoring group stated that "many refugees are desperate to leave the precarity, insecurity and hopelessness in the refugee camps in Bangladesh, in particular those with relatives in Malaysia. They also have no other way to do so rather than undertaking risky journeys by boat, and this, in spite of the vigilance by Bangladesh security forces" (cited in the Star, 2019).

Currently, refugee camps are targeted by human traffickers. Though Bangladeshi law enforcers denied this allegation. Reuters Journalist Ruma Paul (2020) mentioned that, "at least two dozen ethnic Rohingya died on a ship that drifted for weeks after failing to reach Malaysia, Bangladesh coastguard officials said on April,16, following the rescue of 396 starving survivors." Malaysia recently arrested two Rohingya for alleged human trafficking in Langkawi (FMT News, 2020). In this time, due to pandemic COV 19, Malaysian government increased maritime patrols to stop illegal migration. Rohingya leaders argued that human traffickers have strong network from refugee camps to Malaysia. Both countries section of government officials involved here (email conversation with Nurul Islam, Chairman, Arakan Rohingya National Organization). Therefore, it can be stated that human trafficking is now serious concern for Rohingya hosting country like; Bangladesh and Malaysia.

\section{Traditional Security Threat}

Bangladesh has been facing growth of Islamic radicalization. After $9 / 11$ context, it is common phenomena in any Muslim dominated countries. Over the year, there is an increasing fear of the radicalization of Rohingya settlements in border areas. In Bangladesh, some local newspapers reported that a section of Rohingya might have links with Islamic militants. It is noted that Cox's Bazar based Daily Cox's Bazar News, Chittagong based Daily Purbokune and some online news portals published a series of reports about the 
Rohingya militancy. Some academics such as; Bhaumik (2010, 2012), Ganguly \& Miliate (2015), argue that some Rohingya organizations have established links with other extremist groups in neighboring Bangladesh. It is not easy to provide accurate information on this allegation.

This study filed work tried to get more information about the militant organizations presence in refugee camps through the conversation with Rohingya political leaders. Ko Ko Linn alias Mohammad Kalim, who was one of the organizers of 88 students' movement in Myanmar shared his views that, "it was strong rumor in social media that Myanmar officials used Aung Zaw Win alias Zakir Ahmed, a Rohingya MP of USDP to form this militant group to save Rohingya community from Rakhine's coercions. Soon after, Aung Zaw Win visited to Saudi Arabia and met selected Rohingya youths including Ata Ullah. Most of the organizers in Arakan Rohingya Salvation Army (ARSA) were born in Pakistan and grown up in Saudi Arabia. Literally, they have no contact with Rohingya ancestor land Arakan (Rakhine State). A few days later, Ata Ullah visited to Yangon and later he entered in Rakhine State via Bangladesh border" (interview, Chittagong, November 9, 2018). The Rohingya dominated Union National Development Party, President- Abu Tahy, who is based in Yangon, strongly against the ARSA's activities and accused to law enforcers who directly-indirectly helped this group of people. It is not unlikely that ARSA conducted their activities from refugee camps (email conversation, January 5, 2019).

ARSA militants have presence in the camps or not; it has strong different opinion between Bangladeshi law enforcers and Rohingya leaders. The law enforcers boldly rejected it but refugee leaders disagree with the Police statement (interview with Police Superintend, November 04, 2018 in Cox's Bazar). This study field work suggested that it is not easy to identify who still maintain the relation with ARSA. Refugee leaders based on camps claimed that ARSA members are conducting their activities especially at night time. Not only the
ARSA, there are few anti-social groups presence in the refugee camps. Another fraction led by Abdul Hakim, it is banditry group and conducted their activities from refugee camps including different places in borderland (interview with anonymous Rohingya refugee leaders in Cox's Bazar and exile Rohingya leaders in Chittagong, November, 2018). This study field work suggested that law enforcers' number is relatively small compare to the whole population. So why, it is not easy to make conclusion the organizational activities of ARSA or militants in the refugee camps. In addition, mainstream Rohingya political parties have been trying to establish their organizational network in the camps.

Earlier it was mentioned that Office of the Refugee Relief \& Repatriation Commissioner is the main government agency who coordinates with UN and international organizations to conduct humanitarian activities in refugee camps. During the discussion, Deputy Refugee Relief and Repatriation Commissioner stated that, "some allegations come in the media that faith based organization especially from Turkey and Pakistani born British citizens misguided the refugees" (interview, Cox's Bazar, November 03, 2018). The police and civil administration had very quickly handle this situation and taken action against the foreign aid workers. Bangladeshi law enforcers stated that "more than a million refugees are living in very small spaces. Crime number is not high compare to overall population in the camps. Bangladesh government has full control over the refugees, though it is hard to manage this large number of population" (interview with Police Superintend, Cox's Bazar, November 04, 2018). In addition, Bangladeshi security analyst Rashid argues that "it is not that no vested efforts have been made to radicalize the stateless Rohingyas. Many have tried and failed because of the strong monitoring from Bangladeshi law enforcement agencies" (Ahmed, 2020). Despite the precautionary measures, it is not easy to say displaced Rohingya have no connections with global terrorist groups. 


\section{Conclusion}

This study has addressed the displaced Rohingya situation in Bangladesh. To fulfill this objective, it was appropriate to know how the Rohingya people treated in Bangladesh. At the same time, study also explored how refugee became security concern for host country. Consequences of the 'Operation Clearance' in Rakhine State on 2017, nearly a million of Rohingya have been compelled to leave Myanmar and seek refuge in Bangladesh. This study, involving two rounds field work at refugee camps in Bangladesh and various data, suggests that displaced Rohingyas vulnerable to human trafficking, food and health insecurity. This study found that within short time, Government of Bangladesh and various international humanitarian agencies handled the refugee influxes as well as try to ensure their basic needs. However, there are some problems raised in camp areas; conflict among the refugees, presence of militants and large scale environmental degradation. The local newspapers and this study field work argued that most of the Rohingya refugees are seeking safety zone for their lives, some people in the camp engaged with anti-social activities.

Despite progress, this study witnessed that the Rohingya situations has not improved in their ancestors' land Rakhine State. Many displaced people urged to go back their home with peace and security. Some of them are reluctant but it does not mean they would like to merge with Bangladeshi community. The fieldwork from this study suggests that Rohingya atrocity and security issue is not confined in Myanmar or Bangladesh. Now it became regionalized. From the state centric point of security, this study argued that few refugees have involvement with militant activities. The large scale of the refugees is innocent. Simultaneously, thousands of refugee people have been grown up without identity and fundamental needs. The humanitarian support currently provided by the international organizations will not continue for a long period. If the displaced Rohingya will stay long period, then burden will befall on the people of Bangladesh.

\section{Acknowledgement}

This study conducted under the project of 'Displaced Rohingya and Concern for NonTraditional Security Risk in Southern Thailand.' It was funded by Faculty of Management Sciences in Prince of Songkla University, Thailand.

\section{REFERENCES}

[1] Adams, B., (2020, February 13). Christians Abducted, Attacked in Bangladesh Refugee Camp: Authorities Should Ensure Safety of All Refugees. Retrieved April 15, 2020, from

https://www.hrw.org/news/2020/02/13/chri stians-abducted-attacked-bangladeshrefugee-camp $>$

[2] Agence France-Presse, (2017). Top Myanmar general defends military's 'clearance operations' as 400,000 Rohingya flee bloodshed, Retrieved December 17, 2019, from https://www.scmp.com/news/asia/southeast -asia/article/2111530/top-myanmargeneral-defends-militarys-clearanceoperations>

[3] Amnesty International, (2018). Myanmar: New evidence reveals Rohingya armed group massacred scores in Rakhine State. Retrieved December 10, 2019, from https://www.amnesty.org/en/latest/news/20 18/05/myanmar-new-evidence-revealsrohingya-armed-group-massacred-scoresin-rakhine-state/>

[4] Alam, M., (2018). How the Rohingya crisis is affecting Bangladesh - and why it matters. The Washington Post, Retrieved May 21, 2019, from https://www.washingtonpost.com/news/mo nkey-cage/wp/2018/02/12/how-therohingya-crisis-is-affecting-bangladeshand-why-it-matters/?noredirect=on>

[5] Ahmed, Z., (2020, February, 13). Is Pakistani intelligence radicalizing Rohingya refugees? Retrieved from April 30, 2020, from https://www.dw.com/en/is-pakistani- 
intelligence-radicalizing-rohingya-

refugees/a-52364548>

[6] Bhaumik, S., (2010). Rohingyas: Nobody's People in Noman's Land. Refugee watch online, [blog] 18 June, Retrieved September 30, 2019, from http://refugeewatchonline.blogspot.com/20 10/06/rohingyas-nobodys-people-innomans-land.html>

[7] Bhaumik, S., (2012, August 16). Myanmar Conflict threatens Regional Stability, Asia Times Online, Retrieved September 30, 2019 , from http://www.atimes.com/atimes/Southeast_A sia/NH16Ae02.html>

[8] Chaijaroenwatana, B \& Haque M.M., (2029). Displaced Rohingya and Concern for Non-traditional Security Risks in Thailand, in Asian Affairs: An American Review Volume 47, 2020 - Issue 3, https://doi.org/10.1080/00927678.2020.176 3537>

[9] Dhaka Tribune, (2017, August 24). Drug smuggling from Myanmar to Bangladesh sees 'sharp rise' Retrieved January 12, 2020, from

https://www.dhakatribune.com/bangladesh/ 2017/08/24/drug-smuggling-myanmarbangladesh-sharp-rise>

[10] FMT News, (2020, April 21). Two detained for bringing Rohingya in boat to Langkawi. Retrieved April 30, 2020, from https://www.freemalaysiatoday.com/catego ry/nation/2020/04/21/2-detained-forbringing-rohingya-in-boat-to-langkawi/>

[11] Fortify Rights, (2020, March 6). Bangladesh: Investigate Abductions, Protect Ethnic-Rohingya Christians (press release). Retrieved March 30, 2020, from https://www.fortifyrights.org/bgd-inv-202003-06/>

[12] Ganguly, S. \& Miliate, B. , (2015, October 15). Refugees and Neighbors: Rohingya in Bangladesh. The Diplomat. Features. South Asia, Retrieved September 23, 2019, from https://thediplomat.com/2015/10/refugeesand-neighbors-rohingya-in-bangladesh/

[13] Huber, C. \& Homer, K., (2020, January 8) Rohingya refugees in Bangladesh: Facts, FAQs, and how to help. Retrieved September 23, 2019, from https://www.worldvision.org/refugeesnews-stories/rohingya-refugeesbangladesh-facts>

[14] Swazo, N., Haque. Tawfique, Haque, M. M., and Nower, T. (2020), The Rohingya Crisis: A Moral, Ethnographic and Policy Assessment, Routledge India.

[15] Haque, M, M., (2014). Rights of Noncitizens and Concern for Security: The Case of Rohingya in Burma and Bangladesh, $\mathrm{Ph}$. D. Mahidol University.

[16] Haque, M. M., (2017). Political Transition in Burma/Myanmar: Status of Rohingya and Other Muslim Minorities in South Asian Journal of Policy and Governance (SJPG). Vol 41, Number 2, ISSN 2091-0207, December 2017.

[17] Human Rights Watch, (2019, August 20). Myanmar/Bangladesh: Halt Rohingya Returns Ensure Refugees' Security, Basic Rights, Equal Access to Citizenship. Retrieved August 30, 2019, from https://www.hrw.org/news/2019/08/20/mya nmar/bangladesh-halt-rohingya-returns $>$

[18] International Organization for Migration, (2018). Bangladesh 2019: Humanitarian Compendium, Retrieved August 30, 2019, from

https://humanitariancompendium.iom.int/ap peals/bangladesh-2019>

[19] International Rescue Committee, (2017, October 23). Rohingya refugees: The world's fastest-growing humanitarian crisis by the numbers. Retrieved April 30,2018, from

https://www.rescue.org/article/rohingyarefugees-worlds-fastest-growinghumanitarian-crisis-numbers>

[20] India Today, (2019, January 10). Rohingya Hindu refugees in Bangladesh want to return 
to Myanmar: US daily, Retrieved December 30, 2019, from https://www.indiatoday.in/india/story/rohin gya-hindu-refugees-in-bangladesh-want-toreturn-to-myanmar-us-daily-1427605-2019$\underline{01-10>}$

[21] Join Response Plan for Rohingya Humanitarian Crisis, (2019). Retrieved January $11, \quad 2020 \quad$, from https://www.who.int/healthcluster/countries/Bangladesh/2019-jrpRohingya-humanitarian-crisis.pdf?ua $=1>$

[22] Khatun, F., (2017, November 11). Implications of the Rohingya Crisis for Bangladesh, Presented discussion in Centre for Policy Dialogue, Dhaka.

[23] Lederer, Edith, M., (2018, October 25). UN investigator: Genocide still taking place in Myanmar, Retrieved June 10, 2019, from https://apnews.com/bb92e8db60444caeba4 787d42c9280e0>

[24] Martin, A., (2005). Environmental conflict between refugee and host communities. Journal of peace research 42(3): 329-346. (C) 2005 Journal of Peace Research, vol. 42, no. 3,2005, pp. 329-Retrived from April 11, 2019, from http://jpr.sagepub.com DOI 10.1177/00223433050520>

[25] OHCHR, (2018, September 18). Myanmar: UN Fact-Finding Mission releases its full account of massive violations by military in Rakhine, Kachin and Shan States. Retrieved April 12, 2020, from https://www.ohchr.org/EN/HRBodies/HRC /Pages/NewsDetail.aspx?NewsID $=23575>$

[26] Othman, Z, Haque, M. M and Mat, B. (2019). Rohingya Survivors: Regional Security Implication of Gender Based Violence, Negeri Sembilan: Universiti Sains Islam Malaysia, (USIM) Press.

[27] Paul, R., (2020, April 16). Bangladesh coast guard rescues 396 Rohingya in drifting boat; 24 dead, Reuters, Retrieved April 16, 2020, from https://www.reuters.com/article/usbangladesh-rohingya-ships/bangladesh- coast-guard-rescues-396-rohingya-indrifting-boat-24-dead-idUSKCN21Y0AQ >

[28] Rohingya Refugee Committee, (2020, February 8). Joint Statement on Seeking Justice and Security within the Rohingya Refugee Camps, Press Release (press release).

[29] Safi, M., (2017. September 12). Bangladesh calls on Myanmar to take back Rohingya refugees. Retrieved April 30, 2020,from https://www.theguardian.com/world/2017/s ep/12/bangladesh-sheikh-hasina-calls-onmyanmar-to-take-back-rohingya-refugees>

[30] The Economist, (2015, June 01). The plight of the Rohingyas, Retrieved December 10, 2019, from https://www.economist.com/theeconomist-explains/2015/06/01/the-plightof-the-rohingyas >

[31] The Star Online, (2019). Trafficking threat no deterrent. Retrieved July 11, 2019, from https://www.thestar.com.my/news/regional/ 2019/03/03/trafficking-threat-no-deterrentrohingya-refugees-dreaming-of-malaysiarisk-being-cheated-or-worse/>

[32] UNHCR, (2010). Text of the 1951 Convention Relating to the Status of Refugees, Retrieved December 12, 2019, from

https://www.unhcr.org/3b66c2aa10.html>

[33] UNICEF, (2020, February 10). Expanding education for Rohingya refugee children in Bangladesh. Retrieved May 1, 2020, from https://www.unicef.org/rosa/stories/expandi ng-education-rohingya-refugee-childrenbangladesh>

[34] UNDP (2018, September 18). Environmental impacts of Rohingya influx: A multifaceted problem requires multifaceted responses, Retrieved April 29, 2020, from https://www.bd.undp.org/content/banglades h/en/home/presscenter/pressreleases/2018/0 9/18/Environmental_impacts_of_Rohingya _influx.html>

[35] UNDP, (2019, December 30). Groundwater levels fall drastically around Rohingya 
camps. Retrieved April 15,2020, from https://www.bd.undp.org/content/banglades h/en/home/stories/groundwater-levels-falldrastically-around-rohingya-camps-study.html>

[36] World Food Program, (2020, March 16). Joint Response Plan for Rohingya Humanitarian Crisis: An appeal for US\$ 951 million to assist 1.3 million people. Retrieved April 27, 2020, from https://www.wfp.org/news/joint-responseplan-rohingya-humanitarian-crisis-appealus-951-million-assist-13-m> 